\title{
THE RELATIONSHIP BETWEEN NUMERICAL ABILITY, STUDENTS LEARNING INTEREST, AND ATTENTION OF PARENTS WITH MATH STUDENTS LEARNING OUTCOMES
}

\author{
Maulida Dharmawantia ${ }^{a}$ Uswatun Khasanah ${ }^{b}$ \\ Mathematics Education Study Program Universitas Ahmad Dahlan \\ Jalan Ringroad Selatan, Tamanan, Banguntapan, Bantul, Yogyakarta \\ amaulidadharmawanti.09@gmail.com, $\underline{\text { buswatun.khasanah@pmat.uad.ac.id }}$
}

\begin{abstract}
Results of low mathematics associated with many factors. Numerical ability, students learning interest, and attention of parents are several factors that allegedly associated with students' mathematics learning outcomes. This research has to determine whether or not a positive and significant relationship between Numerical Ability, Students Learning Interest, and Attention of Parents with Math Students Learning Outcomes in Even Semester of an eighth-grade student SMP Negeri 1 Batur Banjarnegara Academic Year of 2015/2016. The population in this research were all student of class VIII in even semester in SMP Negeri 1 Batur academic year 2015/2016 with the total number of 82 students in 4 class. Function random sampling technique to class to take a sample class, as a sample class was class VIII D. Data collection techniques done with test method and the questionnaire method. The instruments test used the test of validity, different power, and reliability testing. Test requirements analysis used normality test, independent, and the linearity test. Analysis of data used linear regression analysis and correlation analysis. The results showed that there was a positive and significant relationship between the ability of numerical, students learning interest, and attention of parents with math learning outcomes with $F_{\text {count }}=$ 24,66974024 and $F_{\text {table }}=3,20$, in order to obtain $F_{\text {count }}>F_{\text {table }}$. Multiple correlation coefficient $(\mathrm{R})$ 0,9017792082 with a learn regression equation $\hat{Y}=11,819+0,421 X_{1}+0,286 X_{2}+0,151 X_{3}$. The relative contribution of $\left(X_{1}\right)=63,40293 \%,\left(X_{2}\right)=27,57733 \%$, and $\left(X_{3}\right)=9,01974 \%$ with a coefficient of determination 0,8132057404 and effective contribution $\left(\mathrm{X}_{1}\right) 51,55963 \%,\left(\mathrm{X}_{2}\right)=$ $22,42604 \%$, and $\left(X_{3}\right)=7,33490 \%$.
\end{abstract}

Keywords: Numerical Ability, Students Learning interest, Parents Attention, The Result of Learning Mathematics.

\section{INTRODUCTION}

Education plays an important role in developing potential in a person. This is relevant to Law No. 20 of 2003 article 1 concerning the notion of education which explains that education is a conscious and planned effort to create a learning atmosphere and learning process so that students actively develop their potential to have religious-spiritual power, self-control, personality, intelligence, noble character, and skills needed by him, society, nation, and country. Based on the data of the Final Semester Examination (UAS) obtained from the eighth grade mathematics teacher of SMP Negeri 1 Batur Banjarnegara, it is known that the number of students who are less than the Minimum Completion Criteria (MCC) is 75 or more than 50\% of 81 students have not yet reached the MCC score that is 70 in Mathematics lessons applied at school. This result shows that students' mathematics learning outcomes are not maximal or still low.

There are several factors that influence the learning outcomes of students of SMP Negeri 1 Batur, Banjarnegara Regency, namely numerical ability, interest in learning and parental attention. Based on an interview with one of the mathematics subject teachers on 15 October 2015 at SMP Negeri 1 Batur, it was revealed that the students' numeric abilities were still low. This can be seen in the students' mistakes in working on the test located on the operation of numbers. In addition, student learning interest is still low. This can be seen when the teacher gives homework that is not done by students and the lack of attention of students in the teaching and learning process.

Based on observations and information on the 15th and 16th of October 2015 at SMP Negeri 1 Batur with several students suggesting that students are less interested in learning mathematics. Some students still think that mathematics is a difficult lesson. This results in a feeling of laziness in student 
learning so that students' understanding and mastery of the material is not good. In addition, students express the causes of students not liking mathematics. Students suggest that mathematics subjects are full of formulas and symbols. Besides that mathematics is full of calculations that make students dizzy. This causes difficulties for students in learning mathematics. Parents' attention to students is also lacking. Based on observations and information from several students, students suggested that parents of students rarely ask about student activities while at school. In addition, when students experience learning difficulties students prefer to ask friends rather than parents of students.

Numerical ability is the ability in a person to solve problems related to numbers such as arithmetic problems, letter series, logic numbers, and numerical problems in the story. As stated (Halim, 2010, p.15) states that numerical ability is the ability of students to solve arithmetic problems, numerical series, letter series, logic numbers, and problems in the story. Numerical ability as one of the factors that influence student learning outcomes. Numerical ability tests are not just counting tests. (Chandra, 2013, p. 3-8) mentions that there are several types of numerical ability tests including:

1. Quantitative tests and mathematical reasoning

This test is useful to measure the ability to analyze, digest, and draw conclusions and measure the level of intelligence and accuracy of a person is looking at the problem in an integrated, systematic, and comprehensive from the point of view.

2. Test/rhythm number

3. Patterned mathematics

This test is a question consisting of columns containing numbers. The column has a certain pattern

4. Counting speed test

5. Accuracy test

In addition to numerical abilities, other factors that also have a relationship with learning outcomes are student learning interests. The interest in learning in this study is the interest in learning about mathematics. The interest in learning is a tendency or awareness of the self in students that makes interest in learning that creates a sense of pleasure and a sense of wanting to know information relating to the sciences that have not been obtained so that a business arises. the emergence of interest in learning is caused by a strong desire to climb dignity or get a good job and want to live happy and happy (Djamarah, 2011, p.191). Interest in a particular subject can influence the learning outcomes of certain lessons, such as the interest in learning about mathematics subjects that can affect the learning outcomes of mathematics. Interest in students can be expressed. (Djamarah, 2011, p.166-167) suggests that interest can be expressed by students with statements that prefer something more than others, active participation in an activity, and give more attention to something that interests them regardless of the other (focus).

As for other factors related to student mathematics learning outcomes, namely the attention of parents. Parental attention can be interpreted as a form of assistance given by parents to their children in the form of direction, supervision, giving needs, and advice so parents can control all children's behavior properly. The role of parents in the child's learning process is very important in providing encouragement and direction for their child. (Nurhayati, 2006, p. 20-27) revealed forms of parental attention including guidance and direction, fulfilling needs, reminding and paying attention to learning activities, and providing supervision and encouragement.

The purpose of this study is to find out whether or not there are:

1. The relationship between numerical ability and student mathematics learning outcomes

2. The relationship between students 'learning interests and students' mathematics learning outcomes

3. The relationship between parental attention and student mathematics learning outcomes

4. The relationship between numerical abilities and students 'learning interests with students' mathematics learning outcomes

5. Relationship between numerical abilities and parents 'attention to students' mathematics learning outcomes 
6. Relationship between student learning interest and parents' attention to student mathematics learning outcomes

7. Relationship between the numerical abilities of students' learning interests and parents' attention to students' mathematics learning outcomes

\section{METHODS}

The type of this study is a type of correlation study with a population of all eighth-grade students of SMP Negeri 1 Batur Banjarnegara Regency in the even semester of the 2015/2016 academic year which amounted to 82 students consisting of 4 classes. Sampling is done using random sampling techniques for the class. The sample of this study amounted to 21 students in class VIII D and class VIII A as a trial class. Data collection techniques used are the test method and questionnaire method. Test for variable numerical abilities and mathematics learning outcomes. While the questionnaire for the variables of student learning interest and attention of parents.

The instruments used are tests and questionnaires. Tests are used to obtain numerical ability data and mathematical learning outcomes, while questionnaires are used to obtain data on student learning interest and parental attention. Tests of learning outcomes on the subject of the circle in the form of test results. Before the instrument was tested in the research class so that the test results of the learning outcomes and numerical abilities arranged did not deviate from the material being taught, then a grid was drawn, test questions, questionnaire questions, and review of the items and trial questionnaire. After the instrument is arranged, then it is tested on the instrument trial class, namely class VIII A. After the test questions are tested, the test items are analyzed by validity test using the product-moment correlation formula, different power using the discrimination index formula, and reliability testing using the formula Kuder Richardson-20 (KR-20). Analysis prerequisite test used the normality test, independent test, and linearity test. Data analysis using linear regression analysis and correlation analysis. In addition, a contribution test was conducted to determine the relative size of the contribution and the effective contribution of numerical abilities, students' interest in learning, and the attention of parents to the mathematics learning outcomes.

\section{RESULTS AND DISCUSSION}

Based on the research that has been carried out obtained data on numerical ability, interest in learning, parental attention, and the results of learning mathematics in SMP Negeri 1 Batur on circle material.

\section{The Normality Test}

Based on the normality test that has been done, it is obtained that the four variables, namely numerical ability, student interest in learning, parental attention, and mathematics learning outcomes are normally distributed. The summary of the results of the normality test can be seen in Table 1 .

Table 1. Normality Test Results

\begin{tabular}{|c|l|c|c|}
\hline No. & \multicolumn{1}{|c|}{ Variable } & $\chi_{\text {count }}^{2}$ & $\boldsymbol{\chi}_{\text {table }}^{2}$ \\
\hline 1. & $\begin{array}{l}\text { Numerical Ability } \\
\left(\mathrm{X}_{1}\right)\end{array}$ & 0,5614 & 5,9915 \\
\hline 2. & Interest to learn $\left(\mathrm{X}_{2}\right)$ & 1,8276 & 5,9915 \\
\hline 3. & Parents attention $\left(\mathrm{X}_{3}\right)$ & 1,8781 & 3,8415 \\
\hline 4. & $\begin{array}{l}\text { Mathematics Learning } \\
\text { Results }(\mathrm{Y})\end{array}$ & 1,0106 & 5,9915 \\
\hline
\end{tabular}

\section{The Independent Tests}

Based on the independent tests that have been conducted, it was found that among the independent variables, namely numerical ability and student learning interest, numerical ability and parental attention, and students' interest in learning and parental attention, it was found that between 
independent and independent variables. The summary of the results of independent tests can be seen in Table 2.

Table 2. Inter Variable Independent Test Results

\begin{tabular}{|l|l|l|l|}
\hline No. & \multicolumn{1}{|c|}{ Variable } & $\chi_{\text {count }}^{\mathbf{2}}$ & $\chi_{\text {table }}^{\mathbf{2}}$ \\
\hline 1. & $\mathrm{X}_{1}$ to $\mathrm{X}_{2}$ & 11,572 & 37,652 \\
\hline 2. & $\mathrm{X}_{1}$ to $\mathrm{X}_{3}$ & 13,706 & 37,652 \\
\hline 3. & $\mathrm{X}_{2}$ to $\mathrm{X}_{3}$ & 13,003 & 37,652 \\
\hline
\end{tabular}

\section{The Linearity Test}

Based on the linearity test that has been done, it was found that between the independent variables and the dependent variable, namely numerical ability with mathematics learning outcomes, numerical students 'interest in learning with mathematics learning outcomes, and numerical parents' attention to mathematics learning outcomes, it was found that there was a linear relationship. The summary results of the linearity test can be seen in Table 3 .

Table 3. Linearity Test Results

\begin{tabular}{|l|l|l|l|}
\hline No. & \multicolumn{1}{|c|}{ Variable } & $\boldsymbol{F}_{\text {count }}$ & \multicolumn{1}{|c|}{$\boldsymbol{F}_{\text {table }}$} \\
\hline 1. & $\mathrm{X}_{1}$ to $\mathrm{Y}$ & 1,516 & 2,92 \\
\hline 2. & $\mathrm{X}_{2}$ to $\mathrm{Y}$ & 1,058 & 3,98 \\
\hline 3. & $\mathrm{X}_{3}$ to $\mathrm{Y}$ & 1,636 & 3,57 \\
\hline
\end{tabular}

4. The Hypothesis Test

a. The first hypothesis

Based on the results of a simple correlation analysis of the t-test, the numerical female correlation coefficient (X1) was obtained with mathematical learning outcomes (Y) of 0.8696798723 and results $t_{\text {count }}=7,679745792$ while $t_{\text {table }}$ at a significant level $5 \% d k=n-2=19$, with $n=$ 21 that is equal to1,729. So that $t_{\text {count }}>t_{\text {table }}$, then the first hypothesis has been tested by refusing $H_{0,1}$ and accept $H_{1,1}$ which means that there is a positive and significant relationship between numerical ability and the mathematics learning outcomes of class VIII SMP Negeri 1 Batur Banjarnegara in Even Semester 2015/2016 Academic Year. Whereas the regression equation is $\hat{Y}=$ $30,275+0,617 X_{1}$.

b. Second hypothesis

Based on the results of a simple correlation analysis - t-test, the correlation coefficient of student learning interest is obtained $\left(\mathrm{X}_{2}\right)$ with mathematics learning outcomes $(\mathrm{Y})$ of 0,8081926194 and result $t_{\text {count }}=5,981865958$ while $t_{\text {table }}$ at a significant level 5\% $d k=n-2=19$, with $n=21$ that is equal to 1,729 . So that $t_{\text {count }}>t_{\text {table }}$, then the first hypothesis has been tested by refusing $H_{0,2}$ and accept $H_{1,2}$. This means there is a positive and significant relationship between students' interest in learning with the mathematics learning outcomes of class VIII SMP Negeri 1 Batur Banjarnegara Regency Even Semester 2015/2016 Academic Year. Whereas the regression equation is $\hat{Y}=9,767+0,834 X_{2}$.

c. Third hypothesis

Based on the results of a simple correlation analysis of the t-test, the correlation coefficient of parental attention is obtained $\left(\mathrm{X}_{3}\right)$ with the results of learning mathematics $(\mathrm{Y})$ was 0,5510685985 and result $t_{\text {count }}=2,87857116$ while $t_{\text {table }}$ at a significant level $5 \% d k=n-2=19$, with $n=$ 21 that is equal to 1,729 . So that $t_{\text {count }}>t_{\text {table }}$, then the first hypothesis has been tested by refusing $H_{0,3}$ and accept $H_{1,3}$.This means there is a positive and significant relationship between the attention of parents with the mathematics learning outcomes of class VIII students of SMP Negeri 1 Batur Banjarnegara Regency in Even Semester 2015/2016 Academic Year. Whereas the regression equation is $\hat{Y}=25,391+0,625 X_{3}$. 
d. Fourth hypothesis

Based on multiple correlation analysis, the multiple correlation coefficient $(\mathrm{R})$ is obtained between numerical ability $\left(\mathrm{X}_{1}\right)$ and student learning interest $\left(\mathrm{X}_{2}\right)$ with student learning outcomes $(\mathrm{Y})$ of 0,8947349203 , double top linear regression equation $\mathrm{X}_{1}, \mathrm{X}_{2}$ is $\hat{Y}=17,395+0.433 X_{1}+$ $0,344 X_{2}$. Furthermore, in testing the significance of the correlation coefficient using the F-test, it was obtained $F_{\text {count }}=36,101862$ while $F_{\text {table }}=3,55$ at a significant level of 5\%, $v_{1}$ numerator $=2$ and $v_{2}$ numerator $=18$. So that it is obtained $F_{\text {count }}>F_{\text {table }}$, therefore $H_{0,4}$ rejected and $H_{1,4}$, so there is a positive and significant relationship between numerical ability and students' interest in learning with the mathematics learning outcomes of students at SMP Negeri 1 Batur Banjarnegara District in Academic Year 2015/2016.

e. Fifth hypothesis

Based on multiple correlation analysis, we obtain a multiple correlation coefficient (R) between numerical ability $\left(\mathrm{X}_{1}\right)$ and parental attention $\left(\mathrm{X}_{3}\right)$ with student learning outcomes $(\mathrm{Y})$ of 0.8862753319 , double linear regression equation for $\mathrm{X}_{1}, \mathrm{X}_{3}$ is $\hat{Y}=19,079+0,555 X_{1}+0,218 X_{3}$. Furthermore, in testing the significance of the correlation coefficient using the F-test, it was obtained $F_{\text {count }}=32,95490539$ while $F_{\text {table }}=3,55$ at a significant level of $5 \%, v_{1}$ numerator $=2$ and $v_{2}$ numerator $=18$. So that it is obtained $F_{\text {count }}>F_{\text {table }}$, therefore $H_{0,5}$ is rejected and $H_{1,5}$, so there is a positive and significant relationship between numerical ability and the attention of parents with the mathematics learning outcomes of students at SMP Negeri 1 Batur Banjarnegara in the 2015/2016 Academic Year.

f. Sixth hypothesis

Based on multiple correlation analysis, the multiple correlation coefficient (R) between student learning interest $\left(\mathrm{X}_{2}\right)$ and parental attention $\left(\mathrm{X}_{3}\right)$ with student learning outcomes $(\mathrm{Y})$ is 0.8218054484 , double linear regression equation over $\mathrm{X}_{2}, \mathrm{X}_{3}$ is $\hat{Y}=2,718+0,739 X_{2}+0,198 X_{3}$. Furthermore, in testing the significance of the correlation coefficient using the F-test, it was obtained $F_{\text {count }}=18,72337451$ while $F_{\text {table }}=3,55$ at a significant level of $5 \%, v_{1}$ numerator $=2$ and $v_{2}$ numerator $=18$. So that it is obtained $F_{\text {count }}>F_{\text {table }}$, therefore $H_{0,6}$ is rejected and $H_{1,6}$, so there is a positive and significant relationship between students' interest in learning and the attention of parents with the mathematics learning outcomes of students of SMP Negeri 1 Batur Banjarnegara District 2015/2016 Academic Year.

g. Seventh hypothesis

Based on multiple correlation analysis with three independent variables, a multiple correlation coefficient $(\mathrm{R})$ was obtained between numerical ability $\left(\mathrm{X}_{1}\right)$, student learning interest $\left(\mathrm{X}_{2}\right)$, and parental attention $\left(\mathrm{X}_{3}\right)$ with student learning outcomes $(\mathrm{Y})$ of 0.9017792082 , equation double linear regression of $\mathrm{X}_{1}, \mathrm{X}_{2}$, and $\mathrm{X}_{3}$ is $\hat{Y}=11,819+0,421 X_{1}+0,286 X_{2}+0,151 X_{3}$. Furthermore, in testing the significance of the correlation coefficient using the F-test, it was obtained $F_{\text {count }}=$ 24,66974024 while $F_{\text {table }}=3,20$ at a significant level $5 \%, v_{1}$ numerator $=3$ and $v_{2}$ numerator $=$ 17. so that it is obtained $F_{\text {count }}>F_{\text {table }}$, therefore $H_{0,7}$ rejected and $H_{1,7}$, so there is a positive and significant relationship between numerical ability, students 'learning interest, and parents' attention to the mathematics learning outcomes of students of SMP Negeri 1 Batur Banjarnegara in Academic Year 2015/2016.

The relative contribution size and the amount of effective contribution for each variable X1, $\mathrm{X} 2$, and $\mathrm{X} 3$ with y variables can be seen in Table 4 .

Table 4. Summary of Relative Donations and Effective Donations

\begin{tabular}{|c|c|c|}
\hline Variable & Relative Donations ( \%) & Effective Donations ( \%) \\
\hline$X_{1}$ & $63,40293 \%$ & $51,55963 \%$ \\
\hline$X_{2}$ & $27,57733 \%$ & $22,42604 \%$ \\
\hline$X_{3}$ & $9,01974 \%$ & $7,33490 \%$ \\
\hline total & $100 \%$ & $81,32057 \%$ \\
\hline
\end{tabular}




\section{CONCLUSION}

Based on the results of research and discussion, conclusions can be drawn, namely:

1. There is a positive and significant relationship between numerical ability and mathematics learning outcomes of class VIII students of SMP Negeri 1 Batur Banjarnegara in even semester of the 2015/2016 Academic Year.

2. There is a positive and significant relationship between students' learning interest and the mathematics learning outcomes of class VIII students of SMP Negeri 1 Batur Banjarnegara in the even semester of the 2015/2016 Academic Year.

3. There is a positive and significant relationship between the attention of parents with the mathematics learning outcomes of class VIII students of SMP Negeri 1 Batur Banjarnegara in the even semester of the 2015/2016 Academic Year.

4. There is a positive and significant relationship between numerical ability and students' learning interest with mathematics learning outcomes of class VIII students of SMP Negeri 1 Batur Banjarnegara in the even semester of the 2015/2016 Academic Year.

5. There is a positive and significant relationship between the numerical abilities and attention of parents with the mathematics learning outcomes of class VIII students of SMP Negeri 1 Batur Banjarnegara in the even semester of the 2015/2016 Academic Year.

6. There is a positive and significant relationship between students' interest in learning and the attention of parents with the mathematics learning outcomes of class VIII students of SMP Negeri 1 Batur Banjarnegara in the even semester of the 2015/2016 Academic Year.

7. There is a positive and significant relationship between numerical ability, students 'interest in learning and parents' attention to the mathematics learning outcomes of class VIII students of SMP Negeri 1 Batur Banjarnegara in the even semester of the 2015/2016 Academic Year.

\section{SUGGESTION}

Based on the conclusions above, then some suggestions that researchers can express as follows:

1. With numerical skills and high interest in learning, a student has the capital to get good mathematics learning outcomes, so it should improve numerical abilities.

2. Schools are expected to have higher attention and concern with efforts to improve and improve the quality of education by paying attention to factors that can affect student learning outcomes. the school must have a good relationship or relationship with parents so that communication is established regarding student learning progress.

3. Parents are expected to create a conducive home learning environment, guide their children in learning at home, give encouragement to always be high achievers, give more attention to their children in learning.

\section{REFERENCES}

Halim, Widha , dan Supurwoko. 2011. Hubungan antara Kemampuan Awal dan Kemampuan Numerik dengan Hasil Belajar Fisika Siswa SMP. Tersedia pada : http://core.ac.uk/download/pdf/16506561.pdf. Diakses pada tanggal 2 Desember 2015

Chandra, Aristo dan Tim. 2013. Fresh Up Date Top No.1 Psikotes. Jakarta :Wahyumedia. Djamarah, Syaiful Bahri. 2011. Psikologi Belajar. Jakarta: PT. Rineka Cipta.

Nurhayanti . 2006. Pengaruh Perhatian Orang Tua terhadap Prestasi Belajar Siswa di MA Miftahul Ulum Ngeplak. Demak. Tersedia pada http://library.walisongo.ac.id/digilib/files/disk1/26/jtptiain-gdl-s1-2006-nurharyant-1255bab2.pdf. Diakses pada tanggal 3 Juli 2015. 